\title{
Ethnomedicinal plants and novel formulations used by Hooralis tribe in Sathyamangalam forests, Western Ghats of Tamil Nadu, India
}

\author{
P. Revathi, T. Parimelazhagan* and S. Manian \\ Department of Botany, Bharathiar University, Coimbatore- 641 046, Tamil Nadu, India.
}

Accepted 12 July, 2013

\begin{abstract}
An ethnobotanical survey was carried out in Vilangombai village, Sathyamangalam forest division, Western Ghats of Tamil Nadu, India from November 2011 to January 2012. Information gathered are from the Hooralis tribe about the plant's local name, parts used, preparations and ailments. A total of 47 plant species belonging to $\mathbf{3 0}$ families were collected in the present study. Out of which, 15 plants uses were reported for the first time from this area. The documented diseases were grouped into 12 ailment categories, based on the body system treated. Herbs were recorded under maximum life forms in the documented plants. Leaves were used and paste was the common way of herbal preparation among the studied tribals. The collected data were analyzed for the use value (UV), informant consensus factor (Fic) and fidelity level (FL). The high use reports were recorded in dermatological infection/diseases. The significant Fic values were recorded for gastro intestinal ailments, poisonous bites and dermatological infections. The plants with desirable data obtained in the present study are suggested for evaluating further research and searching new drugs.
\end{abstract}

Key words: Sathyamangalam forest, Vilangombai, Hooralis, formulation, fidelity level, informant consensus factor.

\section{INTRODUCTION}

Plants have always played a major role in the treatment of human traumas and diseases worldwide (Principe, 1991). They have always been used as a source of drugs employed in modern medicine, either by providing pure compounds, starting materials for partial synthesis of useful compounds or models for synthesis of new drugs (Hansel, 1972). Ethnobotany, the largest sub-discipline of ethnobiology, is generally defined as the "science of people's interaction with plants" (Turner, 1995). Ethnobotany stands at a crossroads between social and biological sciences; ethnobotanists have the responsibility to address the importance of wild medicinal plants and documentation of indigenous knowledge through ethnobotanical studies is important for the conservation and utilization of biological resources (Muthu et al., 2006). Therefore, establishment of local names and documentation of the indigenous uses of plants has significant potential societal benefits $\left(\mathrm{Ba}^{\mathrm{gcl}}\right.$, 2000).

India possesses a rich flora of flowering plants with a high degree of endemics and the vegetation in Indian sub-continent is distributed mainly in the Himalayas, Western and Eastern Ghats. Recently, announcement regarding the Western Ghats has made it to the coveted 


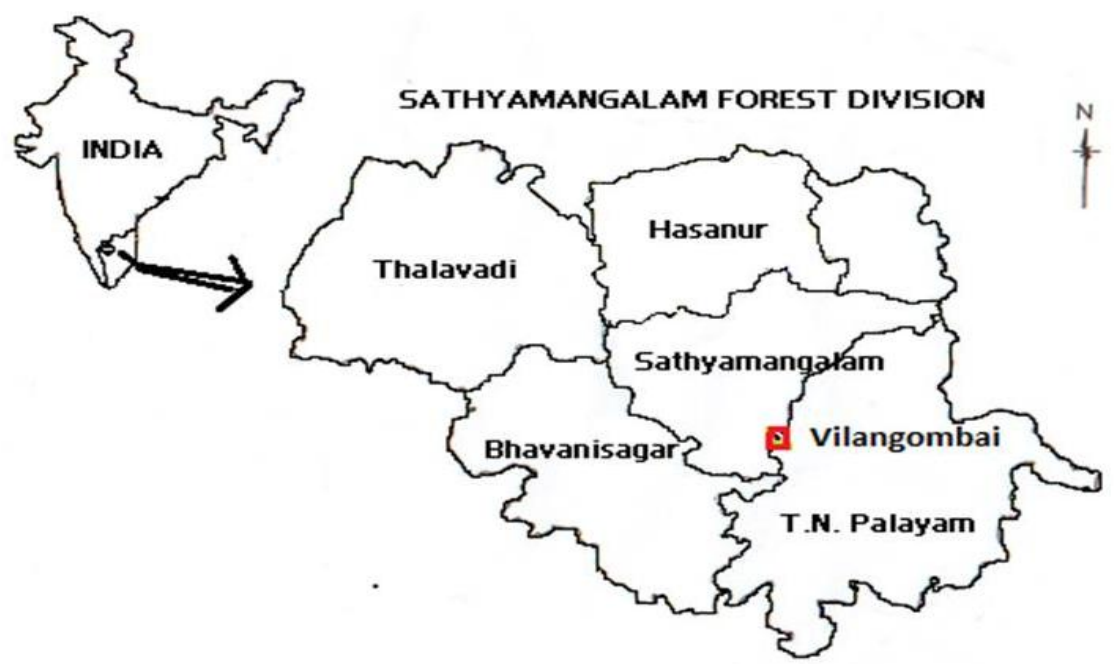

Figure 1. Location map of the study area, Vilangombai, satyamangalam forests, Western Ghats of Tamil Nadu.

list of World Heritage Sites giving more support to this survey. This represents the Western Ghats with properties which are "outstanding examples representing significant ongoing ecological and biological processes in the evolution and development of terrestrial, freshwater, coastal and marine ecosystems and communities of plants and animals", "the most important and significant natural habitats for in situ conservation of biological diversity, including those containing threatened species of outstanding universal value from the point of view of science or conservation".

Though the main task of this study was to conserve such heritage sites, and also to get an awareness of each species and their benefit should also be emphasized. This knowledge can be exploited for prospecting novel drugs where surgery is the mainstay of intervention (Barnert and Messmann, 2008). Even comprehension of scattered knowledge about medicinal plants among tribes is one of the main objectives and exploring the therapeutic potential of wild plants is the ultimate goal of this study. This is the first ethnobotanical study carried out in Sathyamangalam forest area of Western Ghats and is initiated with an aim to identify knowledgeable resource persons among the Hooralis tribals with quantitatively analyzed indigenous ethnomedicinal knowledge through various ethnobotanical tools (use value, informant consensus factor and fidelity level) on the utilization of commonly used medicinal plants.

\section{MATERIALS AND METHODS}

\section{Study area}

Sathyamangalam forest is grouped into four divisions and having number of different tribal groups. Sathyamangalam is a reserved forest including Vilangombai (Figure 1). The total forest area is around $1411.6 \mathrm{~km}^{2}$; in which the present study area is situated with an altitude of $860 \mathrm{msl} 11^{\circ} 37^{\prime \prime} 60^{\prime} \mathrm{N}$ latitude and $77^{\circ} 20^{\prime \prime} 60^{\prime} \mathrm{E}$ longitude. Vegetation of Sathyamangalam forests is a mixed dry deciduous (Plate 1) in nature and southern side of Western Ghats which extends east from the Nilgiri Mountains. The reserved forest area of Sathyamangalam is close to the border of the adjoining state of Karnataka. Since this forest is one part of the components of Western Ghats which have been enrich with many endemic plant and animal species.

\section{Traditional healers}

The main challenge in any ethnobotanical survey is to find persons who still having traditional knowledge of plants in their environs. This study focused on local inhabitants who use traditional resources for common health problems. Information given here is collected from rural dwellers of Vilangombai village, belongs to the tribal community Hooralis (Plate 2), who have been seeking their income in plains. Though their mother tongue is Kannada (mother tongue of bordering state Karnataka), they were interacting well in Tamil language, the mother tongue of Tamil Nadu. Ethnobotanical survey was conducted from November 2011 to January 2012. Information on ethnomedicinal uses was compiled through interviews by an uncomplicated instrument (questionnaire) which was used to detain their answers to the following questions: Does the person know the plant? Can the person recall a name for the plant? Can the person recall any uses for the plant? It is like Martin (1995) method with some modifications.

In addition to these, general conversations were also undertaken to fulfill the data regarding other uses of collected plants. The acquired data were cross-checked from other local informants either by showing the plant specimen or notifying the local names of plants. The plants were initially identified by their vernacular names through consultation with the local people. The scientific identification of plants was done with the help of taxonomist at Bharathiar University. The voucher specimens of collected plants were deposited in the herbarium of Department of Botany, 
Bharathiar University, Coimbatore, Tamil Nadu, India.

\section{Ailment category}

Information collected from the survey was grouped into 12 different ailment categories according to the body system in which the plant was used for treatment. It includes endocrinal system disorders, dental care, general health problems, ENT problems, respiratory system disorders, fever, skeleto muscular system disorders, poisonous bites, dermatological disorders, gastro intestinal system disorders, genito-urinary system disorders and nervous problems (Table 1). These 12 categories include 40 different types of disorders/diseases.

\section{Data analysis}

\section{Use value (UV)}

The relative importance of each plant species known locally to be used as herbal remedy is reported as UV and it was calculated using the following formula (Barnert and Messmann, 2008):

$$
U V=\frac{\Sigma U}{n}
$$

where UV is the use value of a species, $U$ is the number of usereports cited by each informant for a given plant species and $n$ is the total number of informants interviewed for a given plant. The UV is helpful in determining the plants with the highest use (most frequently indicated) in the treatment of an ailment. UVs are high when there are many use-reports for a plant and low when there are few reports related to its use.

\section{Fidelity level ( $F L)$}

$\mathrm{FL}$ is used to determine the most frequently used plant species for treating a particular ailment category by the informants of the study area. The FL was calculated using the following formula (Martin, 1995):

$$
F L(\%)=\frac{N p}{N} \times 100
$$

where $\mathrm{Np}$ is the number of use-reports cited for a given species for a particular ailment category and $\mathrm{N}$ is the total number of usereports cited for any given species. Generally, high FLs are obtained for plants for which almost all use-reports refer to the same way of using it, whereas low FLs are obtained for plants that are used for many different purposes (Heinrich et al., 1998).

\section{Informant consensus factor (Fic)}

Fic was used to see if there was an agreement in the use of plants in the ailment categories between the plant users in the study area. The Fic was calculated using the following formula (Ba gcl, 2000):

Fic $=\frac{N u r-N t}{N u r-1}$

Where Nur refers to the number of use-reports for a particular ailment category and $\mathrm{Nt}$ refers to the number of taxa used for a particular ailment category by all informants. The product of this factor ranges from 0 to 1. A high value (close to 1.0) indicates that relatively few taxa are used by a large proportion of informants. A low value indicates that the informant's disagree on the taxa to be used in the treatment within a category of illness. This method is used to check the homogeneity of information among the users. Fic values will be low (close to 0 value) if plants are chosen randomly or if informants do not exchange information about their use and values will be high (close to 1 value) if there is a well-defined selection criterion in the particular community or if information is transmitted between the informants (Kaya, 2006).

\section{RESULT AND DISCUSSION}

The indigenous population still relies to a great extent on traditional medicinal plants to meet their healthcare needs, because of the perceived effectiveness, presumed safety with minimal side effects and affordability. However, such ethnobotanical information and local plant traditional knowledge needs to be substantiated by pharmacological experiments for scientific validation (Doi Tarak et al., 2011).

\section{Profile of informants}

Population of tribal people in this study area is very less (around 70 families) and there were no well developed transport facilities to the nearby cities. So there is a necessity to walk $5 \mathrm{~km}$ from their villages to the road and it was very difficult, while crossing the small streams during the rainy seasons. Totally, 26 informants (20 males and 6 females) were interviewed; all were illiterates who shared their experience very well during the documentation of ethnomedicinal information. There was no considerable uniqueness as herbalists, ritualists or healers among the informants. All are practicing as per what their parents and grandparents trained them. Nobody was familiar with the entire or general knowledge of all available plant resources in their environs and most of them were familiar with treatment of particular ailments. They diagnose diseases based on the symptoms specified by the patients as well as based on their personal experience in treating ailments. On the other hand, they were anticipating money for sharing their knowledge on medicinal plants to us on whatever information provided by them, which may or may not be new in our point of view, since this was also one of the professions undertaken by them for their livelihood.

\section{New record}

In this study, 47 plant species have been recorded belonging to 30 families with ethnomedicinal properties (Table 2). The information regarding local name, parts 
Table 1. Ailments grouped by different ailment categories.

\begin{tabular}{|c|c|c|}
\hline Ailment category & Biomedical term & Tamil term \\
\hline \multirow{2}{*}{ Dental care(DC) } & Toothache & Pal vali \\
\hline & Worms in gums and teeth & Pal sothai \\
\hline \multirow{12}{*}{ Dermatological Infection/Diseases (DID) } & Blisters & Koppalam \\
\hline & Boils & Achi \\
\hline & Burnings & Thol erichal \\
\hline & Eczema & Ooral \\
\hline & Felon & Nagachuthu \\
\hline & Fungal infection on head & poduhu \\
\hline & Itching & Sori \\
\hline & Prickles & Verkuru \\
\hline & Psoriasis & Sirangu \\
\hline & Skin roughness & Thol varatchi \\
\hline & Worms in skin & Puluvettu \\
\hline & Wounds & Kaayam \\
\hline Ear Nose Throat problems (ENT) & Earache & Kaadhu vali \\
\hline Endocrinal disorders(ED) & Diabetes & Neerilivu \\
\hline Fever(FVR) & Fever & Kaichal \\
\hline \multirow{5}{*}{ Gastro Intestinal ailments (GIA) } & Diahorrea & Vayitrupokku \\
\hline & Intestinal worms & Kudal pulu \\
\hline & Digestion troubles & Ajeeranam \\
\hline & Mouth ulcer and intestinal ulcer & Vaippun \\
\hline & Stomach upset & Vayitru porumal \\
\hline \multirow{2}{*}{ General health problems (GHP) } & Body heat & Udal soodu \\
\hline & Insomnia & Thookaminmai \\
\hline Genito urinary ailments (GUA) & Leucorrhoea & Vellai paduthal \\
\hline Nervous system disorder (NSD) & Seizure & Valippu \\
\hline \multirow{6}{*}{ Poisonous Bites (PB) } & Centipede bites & Pooran kadi \\
\hline & Dog bites & Nai kadi \\
\hline & Poisonous bites & Poochikadi \\
\hline & Scorpion bites & Thel kadi \\
\hline & Snake bites & Pambu kadi \\
\hline & Rat bites & Eli kadi \\
\hline \multirow{3}{*}{ Respiratory system diseases (RSD) } & Asthma & Moochu thinaral \\
\hline & Cold \& cough & Sali, irumal \\
\hline & Breathing troubles & moochadaipu \\
\hline \multirow{5}{*}{ Skeleto muscular system disorders (SMSD) } & Body pain & Udal vali \\
\hline & Bone fracture & Elumbu murivu \\
\hline & Headache & Thalai vali \\
\hline & Joint pain & Moottu vali \\
\hline & Swellings & veekkam \\
\hline
\end{tabular}


Table 2. List of medicinal plants used by Hooralis tribe of of Vilangombai, Sathyamangalam forests, Tamil Nadu, India.

\begin{tabular}{|c|c|c|c|c|c|c|c|}
\hline Botanical name , Family (Voucher No.) & Local name & Life form & Parts used & Preparation & Administration & Ailment category:use reports & $\begin{array}{l}\text { Use } \\
\text { value }\end{array}$ \\
\hline Abutilon indicum(Link.) Sweet Malvaceae (SV 003122) & Thuthi & Shrub & Leaf & Paste & Topical & DID: 10, skin roughness, prickles. & 1.10 \\
\hline Acaceae leucocephala (Roxb.) Willd. Mimosaceae (SV003145) & Velvelam & Small tree & Bark & Infusion & Topical & SMSD:5, bone fracture & 0.60 \\
\hline Achyranthus aspera L. Amaranthaceae (SV003125) & Nayuruvi & Herb & Leaf & Paste & Oral & GIA:6, digestion troubles & 1.00 \\
\hline Acalypha alnifolia Klein. ex. Willd Euphorbiaceae (SV003103) & Solapori thalai & Sub shrub & Leaf & Paste & Topical & DID:2, prickles & 1.00 \\
\hline \multirow{2}{*}{ Acalypha indica L. Euphorbiaceae (SV003131) } & \multirow{2}{*}{ Kuppai meni } & \multirow{2}{*}{ Herb } & \multirow{2}{*}{ Whole plant } & \multirow{2}{*}{ Paste } & \multirow{2}{*}{ Topical } & $\mathrm{PB}: 2$, rat bite & \multirow{2}{*}{1.16} \\
\hline & & & & & & DID:5, eczema & \\
\hline Anisomeles malabarica (L.) R. Br. ex. Sims. Lamiaceae (SV003124) & Peimiratti & Shrub & Leaf & Paste & Oral & GUA:3, leucorrhea & 0.75 \\
\hline \multirow{2}{*}{ Amaranthus cruentus L. Amaranthaceae (SV003141) } & \multirow{2}{*}{ Sivapu pasiri } & \multirow{2}{*}{ Herb } & \multirow{2}{*}{ Leaf } & \multirow{2}{*}{ Paste } & \multirow{2}{*}{ Oral } & GUA:4, leucorrhea & \multirow{2}{*}{0.66} \\
\hline & & & & & & GHP: 2, Body heat & \\
\hline Amaranthus spinosus L. Amaranthaceae (SV003127) & Mullu keerai & Herb & Root & Paste & Topical & DID:4, wounds, blisters & 1.25 \\
\hline Bauhinia tomentosa L. Fabaceae (SV003126) & Aathi & Tree & Bark & Paste & Oral & GIA:3, diahorrea & 1.00 \\
\hline Barleria prionitis L. Acanthaceae (SV003102) & Kattu sulli & Herb & Leaf & Paste & Topical & DID:8, wounds, eczema & 1.60 \\
\hline Boerhaavia diffusa L. Nyctaginaceae (SV003129) & Mukkarattai & Herb & Leaf & Paste & Topical & DID:4, wounds, blisters & 0.80 \\
\hline \multirow{2}{*}{ Boussingaultia baselloides Basellaceae (SV003109) } & \multirow{2}{*}{ Kaarai kodi } & \multirow{2}{*}{ Climber } & \multirow{2}{*}{ Leaf } & \multirow{2}{*}{ Paste } & \multirow{2}{*}{ Oral } & PB:5, snake bite, & \multirow{2}{*}{1.50} \\
\hline & & & & & & DID:1, eczema & \\
\hline Calotropis gigantea (L.) W. T. Aiton. Asclepiadaceae (SV003134) & Velleruku & Shrub & Root & Paste & Topical & DID: 8,eczema, psoriasis & 1.14 \\
\hline Canavalia virosa (Roxb.) Wight \& Arn. Fabaceae (SV003110) & Esakottai & Climber & Leaf & Paste & Topical & SMSD:2, body pain & 1.00 \\
\hline Carica papaya L. Caricaceae (SV003114) & Pappali & Small tree & Latex & Raw & Oral & DC:7, toothache & 1.00 \\
\hline \multirow{2}{*}{ Cardiospermum helicacabum L. Sapindaceae (SV003146) } & \multirow{2}{*}{ Botli chedi } & \multirow{2}{*}{ Climber } & \multirow{2}{*}{ Leaf } & \multirow{2}{*}{ Decoction } & Topical & SMSD:7, swellings, burning sense, body pain & \multirow{2}{*}{1.25} \\
\hline & & & & & Oral & RSD:4, asthma & \\
\hline Cassia angustifolia Vahl. Caesalpinaceae (SV003104) & Nila avarai & Herb & Leaf,, root & Paste & Oral & PB:9, scorpion bite, snake bite, centipede bite & 1.12 \\
\hline Chlorophytum tuberosum (Roxb.) Lilliaceae (SV003132) & Panni muttan kilangu & Herb & Tubers & Paste & Topical & PB:4, centipede bites, poisonous bites & 2.00 \\
\hline Chloroxylon swietenia Dc. Flinderaceae (SV003142) & Porasam & Tree & Leaf & Paste & Topical & DID:8, psoriasis, prickles & 1.12 \\
\hline Cissus quadrangularis L. Vitaceae (SV003133) & Piranda & Climber & Stem and leaf & Fry & Oral & GIA: 9, digestion troubles & 1.00 \\
\hline Commiphora caudata (Wight \&Arn.) Engler. Burseraceae (SV003144) & Kiluvam & Tree & Bark & Paste & Topical & DID:8, wounds & 1.00 \\
\hline Datura metel| Solanaceae (Svon3120) & Oomathai & Suh shruh & Jeaf root fruits & Dried decoction & Fumigation & NSD:4, seizure & 162 \\
\hline Datura metel L. Solanaceae (SV003120) & Oomathal & Sub shrub & Leat, root, fruits & powder & Topical & DID:8,dandroff, hair growth, worms in skin & 1.62 \\
\hline Dioscorea pentaphylla L. Dioscoreaceae (SV003137) & Valli kilangu & Climber & Tubers & Infusion & Oral & RSD:12, asthma & 1.00 \\
\hline Euphorbia ligularia Roxb. Euphorbiaceae (SV003107) & llai kalli & Shrub & Leaf & Paste & Topical & DID: 5 , eczema, wounds, burnings & 1.60 \\
\hline Euphorbia tirucalli L. Euphorbiaceae (SV003147) & Thiruhu kalli & Shrub & Twig & Fry and Juice & Topical & PB: 5, dog bite & 1.00 \\
\hline Evolvulus alsinoides L. Convolvulaceae (SV003123) & Vettukattu thalai & Herb & Leaf & Paste & Topical & DID:7, wounds & 1.00 \\
\hline & & & Latex & & & GUA:1, leucorrhea & \\
\hline Ficus racemosa L. Moraceae (SV003105) & Athi & Tree & Bark & Raw paste & Oral/Topical & GIA:5, diahorrea & 1.80 \\
\hline & & & Leaf & & & DID:3, eczema & \\
\hline Gynandropsis pentaphylla (L.) Dc. Capparaceae (SV003143) & Vela chedi & Herb & Leaf & Juice & Topical & ENT:11, earache & 1.00 \\
\hline Jasminum angustifolium (L.) Willd. Oleaceae (SV003112) & Kattu malli & Climber & $\begin{array}{l}\text { Leaf tender } \\
\text { twig }\end{array}$ & Fry & Oral & GIA:5, stomach ulcer & 1.80 \\
\hline
\end{tabular}


Table 2. Contd

\begin{tabular}{|c|c|c|c|c|c|c|c|}
\hline & & & & & & GHP: 4, good eye sight & \\
\hline Justicia tranquebariensis L.f. Acanthaceae (SV003138) & Punnaku poodu & Herb & Leaf & Paste & Oral & GIA:8, intestinal ulcer & 1.00 \\
\hline \multirow{2}{*}{ Hibiscus micranthus L. Malvaceae (SV003139) } & \multirow{2}{*}{ Kadalakotta chedi } & \multirow{2}{*}{ Herb } & \multirow{2}{*}{ Leaf } & \multirow{2}{*}{ Decoction } & \multirow{2}{*}{ Topical } & SMSD:2, swellings & \multirow{2}{*}{1.25} \\
\hline & & & & & & DID: 3 , skin burnings & \\
\hline Leucas aspera (Willd.) Link. Lamiaceae (SV003140) & Thumabi & Herb & Root & Paste & Oral & PB:7, snake bite & 1.00 \\
\hline Luffa acutangula (L.) Roxb. Cucurbitaceae (SV003118) & Peerkanga & Climber & Seeds & Powder & Oral & PB: 2, snake bite & 2.00 \\
\hline Malvastrum coromandalianum (L.) Gercke. Malvaceae (SV003136) & Kaalimar & Herb & Leaf & Paste & Topical & DID:1, wounds & 1.00 \\
\hline \multirow{2}{*}{$\begin{array}{l}\text { Mucuna atropurpurium (Roxb.) Dc. ex. White \& Arn. Fabaceae } \\
\text { (SV003121) }\end{array}$} & \multirow{2}{*}{ Thellukai thalai } & \multirow{2}{*}{ Climber } & \multirow{2}{*}{ Leaf } & \multirow{2}{*}{ Paste } & \multirow{2}{*}{ Topical } & SMSD:1, swellings & \multirow{2}{*}{1.00} \\
\hline & & & & & & DID:1, itching & \\
\hline Passiflora foetida L. Passifloraceae (SV003106) & Mosiri & Climber & Leaf & Juice & Oral & RSD: 6 , cold and cough, breathing problem & 1.00 \\
\hline \multirow{4}{*}{ Pongamea pinnata (L.) Fabaceae (SV003111) } & \multirow{4}{*}{ Pungam } & \multirow{4}{*}{ Tree } & \multirow{4}{*}{ Flowers } & \multirow{4}{*}{ Fry } & \multirow{4}{*}{ Oral } & $\mathrm{ED}: 7$, diabetes & \multirow{4}{*}{1.66} \\
\hline & & & & & & DID: 2, eczema & \\
\hline & & & & & & GIA:3, digestion troubles & \\
\hline & & & & & & PB:3, snake bite & \\
\hline Prosopsis cineraria (L.) Druce Fabaceae (SV003117) & Vanni & Tree & Bark/Lleaf & Powder & Oral & PB: 12 , snake bite, poisonous bite & 1.33 \\
\hline Pergularia daemia (forsk.) Asclepiadaceae (SV003101) & Veliparuthi & Herb & Leaf & Juice & Topical & FVR: 4 , fever & 1.00 \\
\hline Rivea hypocrateriformis (Desr.) Choisy. Convolvulaceae (SV003115) & Minna & Climber & Leaf & Cooked & Oral & GIA:7, stomach upset & 1.00 \\
\hline Phyllanthus emblica L. Phyllanthaceae (SV003119) & Peru nelli & Tree & Twig & Decoction & Oral (gargle) & GIA:4, mouth ulcer & 1.00 \\
\hline \multirow{2}{*}{ Solanum pubescens Ruiz. \& Pav. Solanaceae (SV003108) } & \multirow{2}{*}{ Mullu kathri } & \multirow{2}{*}{ Herb } & Seeds & Fumigate & \multirow{2}{*}{ Oral (Inhale) } & DC: 5 , toothache, worms in gums and teeth & \multirow{2}{*}{1.50} \\
\hline & & & Fruits & Cooked & & GIA:4, worms in digestive tract & \\
\hline \multirow{2}{*}{ Tinospora cardifolia (Thunb.) Miers. Menispermaceae (SV003130) } & \multirow{2}{*}{ Seenthil kodi } & \multirow{2}{*}{ Climber } & \multirow{2}{*}{ Leaf } & \multirow{2}{*}{ Flamed powder } & Toning & DID:2, felon & 150 \\
\hline & & & & & lopıcal & GHP:1, insomnia & 1.50 \\
\hline Toddalia asiatica (L.) Lam. Rutaceae (SV003128) & Sembarapu & Small tree & Leaf & Paste & Topical & DID:6, boils, eczema & 2.00 \\
\hline & & & & & & DID:5, wounds & \\
\hline Strychnos nux-vomica L. Loganiaceae (SV003135) & Etti & Tree & Fruit/Bark & Smashed paste & Topical & FVR:3, fever & 2.00 \\
\hline & & & & & & SMSD:6, body pain, headache & \\
\hline Vitex negundo L. Lamiaceae (SV003113) & Nochi & Shrub & Leaf & Juice & Topical (bathing water) & SMSD:11, joint pain, headache & 1.38 \\
\hline Ziziphus oenoplia L. Rhamnaceae (SV003116) & Pulicha maram & Tree & Bark & Paste & Oral & GIA:5, diahorrea & 1.00 \\
\hline
\end{tabular}

used, ingredients used, method of preparation, mode of administration and applications for treating various ailments were documented. The study includes some new records for different ailments from the study area. There were 15 plants, namely, Dioscorea pentaphylla, Chloroxylon swietenia, Commiphora caudata, Boussingaultia baselloides, Malvastrum

\section{coromandalianum, Canavalia virosa, \\ Family abundant} Chlorophytum tuberosum, Justicia tranqubariensis, Mucuna atropurpurium, Acacia leucocephala, Acalypha alnifolia, Amaranthus cruentus, Euphorbia ligularia, Hibiscus micranthus and Prosopsis cineraria which were never documented before from this study area as well as from the nearby forests.
One common analysis in ethnobotany is to find the relative frequency of useful taxa in the various botanical families. Ethnobotanists have often argued that a high rate of useful species in a family is a direct indicator of importance (major plant families) (34) 


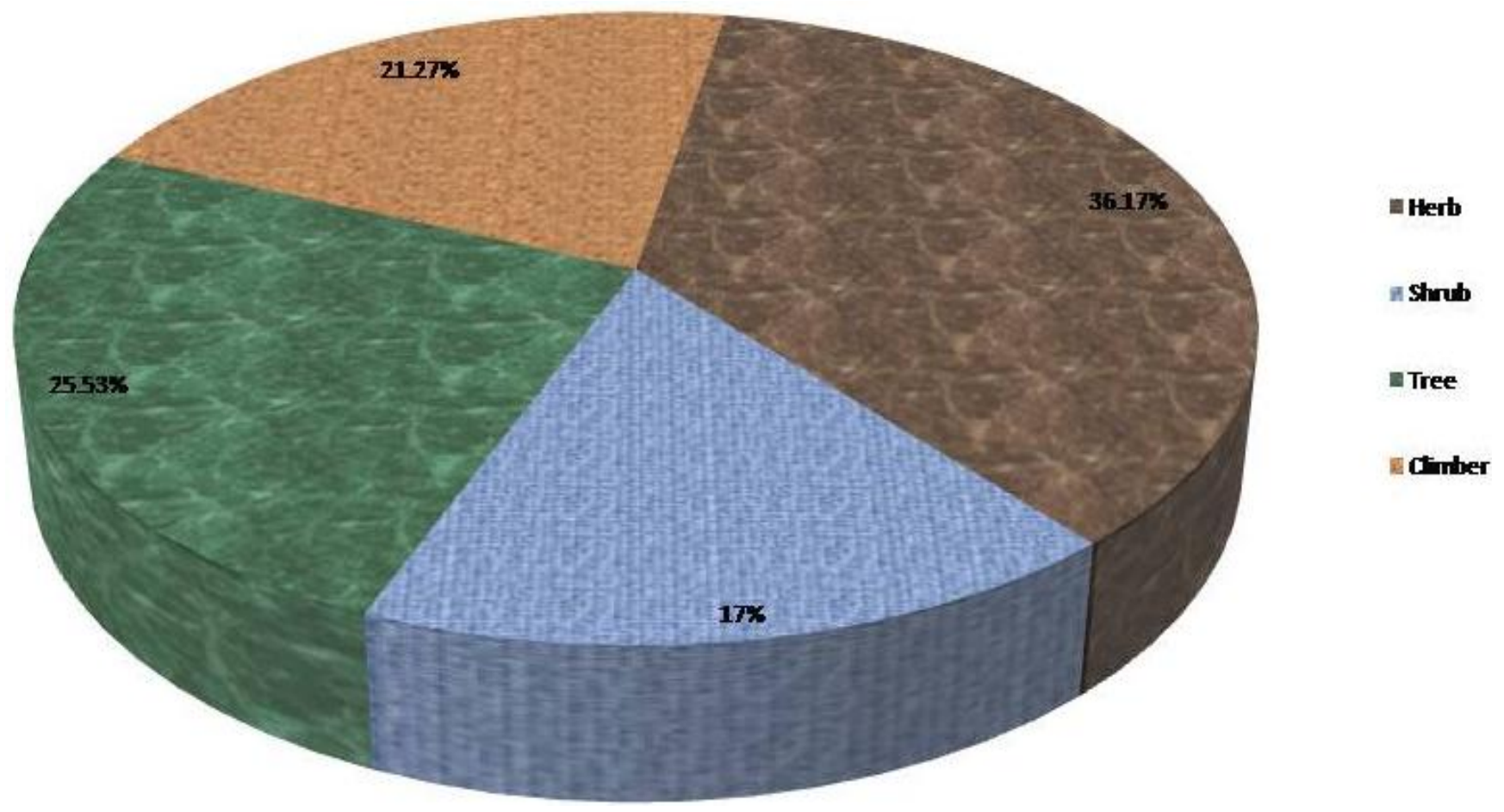

Figure 2. Life forms of collected ethnomedicinal plants.

However, the high species diversity of a particular plant family does not imply that these taxa or the family as a whole is of general dietary relevance (Rivera et al., 2005).

The present study indicates the family Fabaceae was more abundance and get higher importance which is followed by Euphorbiaceae. Many species of the family Acanthaceae and Asclepiadaceae are also frequently used (21 remedies from 12 species) for treating different types of ailments. Ignacimuthu et al. (2006) reported that the families Euphorbiaceae and Solanaceae contribute 9 disorders/diseases treated by 8 species from Madurai district of Tamil Nadu, India. A total of 68 plant species belonging to 37 families were identified from Kalkadambur villages which are used to cure skin diseases, poisonous bites, stomachache, cold, cough and diabetes (Arunachalam and Parimelazhagan, 2011). They reported that, the most common plant families were Euphorbiaceae and Asteraceae (Arunachalam and Parimelazhagan, 2011; Ayyanar and Ignacimuthu, 2011), respectively and there may be some plants which are currently not used for medicinal purposes but which may actually have medicinal effects (Kaya, 2006).

\section{Life forms}

Most of the collected plants in this study were coming under the life form herbs (36\%) followed by trees (25\%), climbers (21\%) and shrubs (Figure 2). Shrubs were recorded as minimum and sub categories like small trees, sub shrubs were under the common life forms. Likewise, in another study, herbs (39 species) were found to be the most used life forms followed by trees, shrubs and climbers (Chellaiah et al., 2006).

\section{Plant parts used}

The parts of the plant mostly used for medicinal purposes in this study are leaves (59\%) which were followed by bark and root. The whole plant used for the treatment is very limited than others (Figure 3). Adetutu et al. (2011) also reported that leaves are the most frequently used plant parts, constituting about $86 \%$ of the preparations followed by stem bark, sap, seeds and fruits in their survey.

\section{Preparation methods}

Traditional knowledge is a dynamic entity which is hybridized with new social, economic, political, and ecological phenomena caused by globalization (Sears et al., 2007). The most common treatment seems to either be using a decoction as a wash followed by application of 


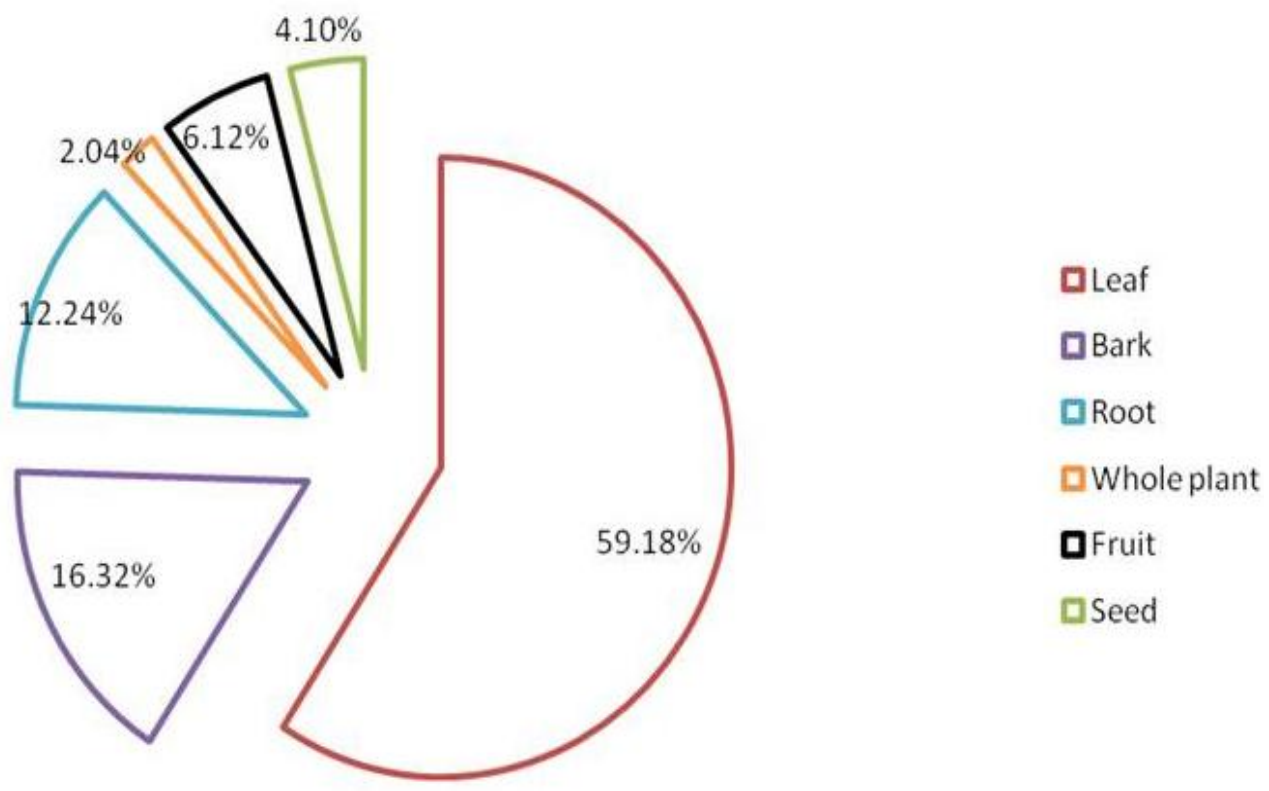

Figure 3. Percentage of plant parts used for the preparation of medicine.

a plant paste or applying a plant dressing directly on the wound (Adetutu et al., 2011). In general, the ethnobotanical studies pointed out that, the common preparation methods includes infusion, decoction, raw, smash, steam, juice, powder, fry, cooked, flamed, paste, latex and fumigated. It is also important to note that in most cases it is very difficult to separate the procedures of decoction and infusion, as pointed out by Mulet (1991) and Bonet et al. (1999). In this study, Hooralis tribal people were preparing herbal medicines as paste $(49 \%)$ which was followed by juice $(9 \%)$, powder $(7 \%)$, cooked and infusion (3\%) (Figure 4).

An old aged tribal practitioner Ahmet Karabulut, stated that when he was angry, he suffered from insomnia; however, when he drank one cup of the Hypericum perforatum tea, he became relaxed and was able to get an uninterrupted sleep (Coleta et al., 2001). The plant products are consumed raw or in the form of a decoction, as infusion for oral treatment and as burnt product, ointments or raw paste when applied externally. Pergularia daemia root bark is mixed with cow milk and used as purgative in treating rheumatism (Senthilkumar et al., 2006). The fresh leaves of $P$. daemia is boiled and inhaled to treat headache (Poongodi et al., 2011) whereas in our survey the same plant is used for fever. The bark decoction of Azadiracta indica is used as liver tonic and the whole plant powder of Cissus quandrangularis is taken orally with cow milk in treating asthma (Alagesaboopathi, 2009). A. indica has also been mentioned as a remedy for malaria in few parts of Africa (Gbeassor et al., 1996). While the whole plant paste of $A$. indica is applied topically to treat rat bite and eczema in the present study (Table 1).

\section{Route of administration}

The route of administration was oral and topical; the later was recorded higher in this study (Figure 5). For topical use, the most important methods used are direct application of paste or ointment (Coleta et al., 2001). In our previous study, it was noticed that SathyamangalamHasanur exploitation shows the mode of administration of these formulations is reverse to this study (Revathi and Parimelazhagan, 2010).

\section{Ingredients added}

Plant parts were harvested as and when needed. None of the informants are supposed to share any particular time and/or day as well as place of harvesting plants as an important factor. Herbal medicines prescribed by tribal people were either preparation based on single plant or a combination of several plant parts. The present study reveals most of the preparations involved other ingredients. Only few plants (30\%) were taken as medicine without any ingredients. In some cases, the added ingredients (Table 3 ) may be other plant parts or some other products like oils, goat milk, and honey. Most of the reported preparations were drawn from mixtures of plant parts. Mostly, fresh plant parts were used for the 


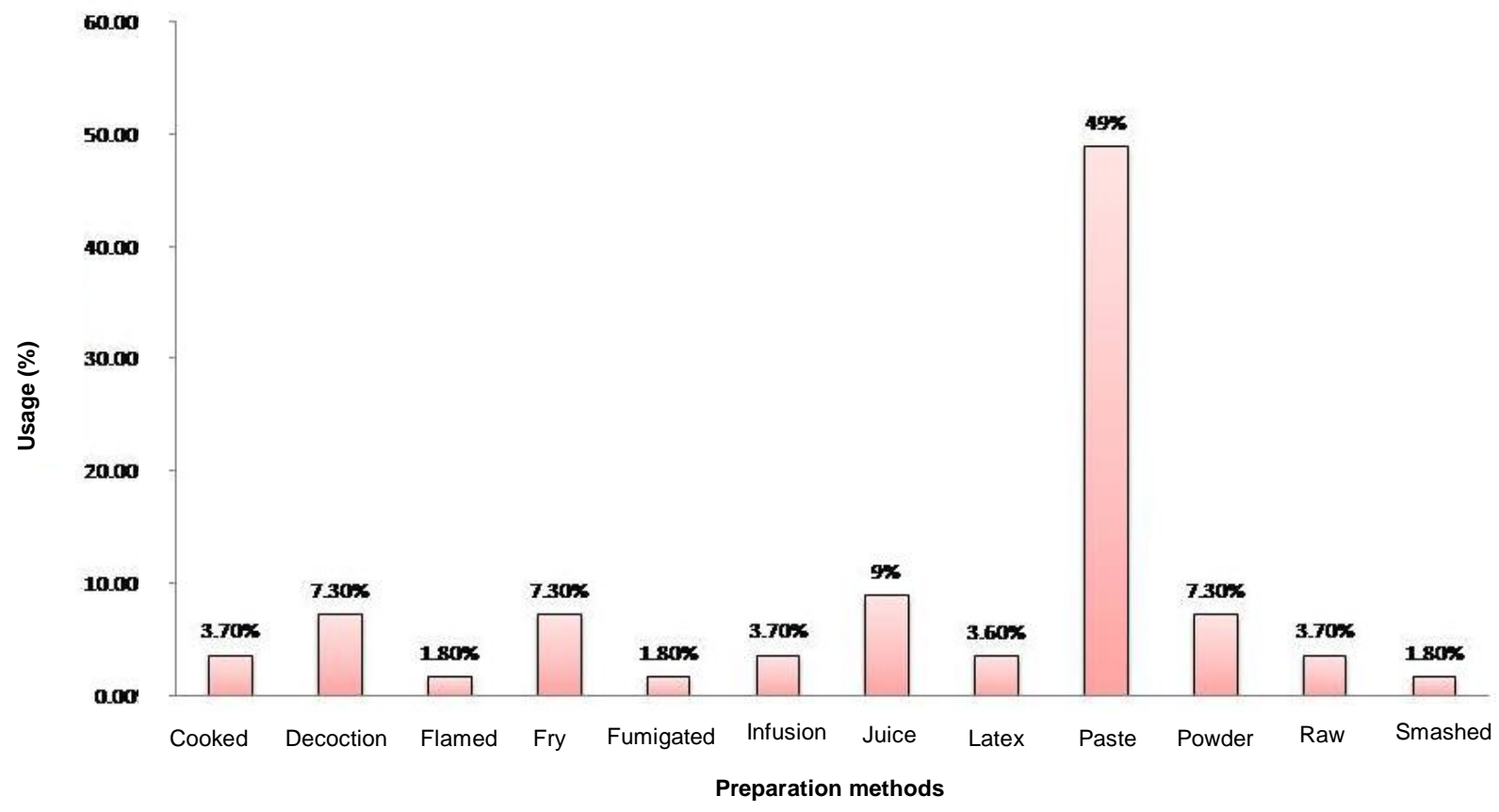

Figure 4. Types of preparation methods for reported ethnomedicinal plants.

\section{Administration Routes}

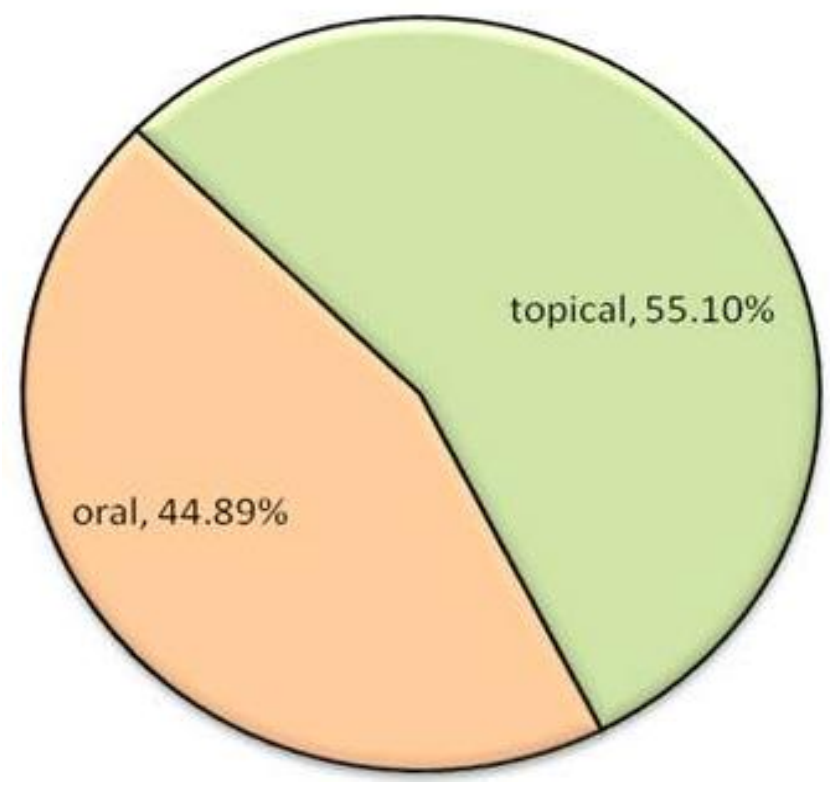

Figure 5. Mode of administration of herbal medicines.

preparation of medicine. Asase et al. (2010) reported that about $73.3 \%$ of the herbal remedies involved the use of a single plant, while about $26.7 \%$ involved a combination of two or more plants.

\section{Novel formulations}

1) Flowers of Pongamia pinnata, Tamarindus indicus along with garlic, cumin seeds, Hemidesmus indicus root and Acorus calamus rhizome were well ground with cow milk which is boiled to reduce the total volume and was filtered. This decoction have to be taken daily for digestive problems and body pain.

2) Flowers of $P$. pinnata taken in iron container with cow ghee and fried upto golden red colour. This is to be shaded dry for $2 \mathrm{~h}$ and store in air tight container. This is taken with hot water daily for diabetes.

3) P. cineraria bark and leaf power is taken with honey for 2 days as 3 times per day to reduce snake venom.

4) Solanum pubescens seeds are dried and fumigated by using dried seeds which are inhaled through mouth to relieve teeth ache due to decay.

5) Garlic, pepper and Cardiospermum helicacabum leaves are chewed well and blown on the patient who is suffering from asthma. When inhale that blown one can give relief from asthma.

6) The root of Calotropis gigantia is pasted with coconut oil and is applied topically to treat skin problems.

7) Fruit, leaf, and root of Datura metal are boiled in water to accomplish decoction which are dried and the powdered decoction is fumigated for fits. 
8) The dried tender twigs of Terrania asiatica is boiled with castor oil. Then cooled to room temperature which is applied topically before bath for fever and sever cold.

9) The tender twigs of Mangifera, Azadiracta, and Pomegranate are ground with milk or curd. This blend is taken orally for diarrhea.

10) The leaf of Anisomilus is squished and ground with Ficus racemosa latex and cumin seeds. This is taken in empty stomach to cure leucorrhea.

\section{Data analysis}

A quantitative analysis of the data obtained during the interviews is of great importance, because it allows us to make macro-scale comparisons of the informant's knowledge (Begossi, 1996). Ethnobotanical tools can be used to analyze two-dimensional contingency matrices. In such matrices, the states of the first descriptor (symptoms) are compared to the states of the second descriptor (species). The limitations of such analysis would be reduced using a larger data set based on more specific symptoms or disorders, and coupled with phytochemical data for the species cited (Leduc et al., 2006). Collected data were processed for use value, informant consensus factor and fidelity level.

\section{Use value}

The ratio between the number of unreported uses and the total number of medicinal plants cited (NRU/P index) is considerably high (1.35), indicating a high degree of knowledge about this matter in the studied area (Novais et al., 2004). This could reveal the value of each species and it proves the necessity of exploring such. Use value (Table 2) is the orientation related to the usage by the people that may be high due to good result by their experience. Otherwise, some of them showing low use value may be due to lack of communication among them or minimum activity. Plants with high use value are used to heal wounds and poisonous bites which are the common disease categories often encountered by the people of that area and they share their knowledge with each other to treat these diseases.

\section{Fidelity level}

From the available information, fidelity level of each of the species was calculated. It indicates the informants choice for each ailments and potential of the species related to the ailments. As part of this study, there are 26 plants that recorded $100 \%$ fidelity level and the lowest $F L$ was recorded for $F$. racemosa (11), P. pinnata (13\%), C. helicacabum (22.22\%) and Strychnos nux-vomica (21\%)
(Table 4). Obviously it shows that the informants gave preference to particular plants for specific ailments. Increasing values of $F L$ for a species indicates its uniqueness to treat a particular illness (Pandikumar et al., 2011).

\section{Informant consensus factor}

Generally, Fic of local knowledge for disease treatment depends on the availability of the plant species in the study area (Rajakumar and Shvanna, 2009). Based on Fic values calculated, the illness categories were classified into three arbitrary groups as proposed by Moerman (2007). The medicinal plants that are presumed to be effective in treating a certain diseases have higher Fic values (Teklehaymanot and Giday, 2007). In the present study, the illness categories that had a high Fic values greater than mean Fic plus standard deviation $(0.845 \pm 0.123)$ were assigned as illness categories with high Fic values. The illness categories which had low Fic values that were lower than mean Fic plus standard deviation were assigned as illness categories with low Fic values. The remaining illness categories were assigned as illness categories with moderate Fic values (Table 5).

When the articles in which the informant consensus factor (ICF or Fic) is calculated are examined, it is seen that, for example in the study of Mesfin et al. (2009), the category: malaria, fever and headache have the highest 0.82 Fic followed by ascariasis and diarrhea, and intestinal parasite and stomach-ache each with 0.78 Fic (Ayyanar and Ignacimuthu, 2011). In this way in our study the ENT problems, endocrinal and nervous system disorders had the highest Fic value (1.00), because the number of taxa documented for those ailments were very low with high use reports. Hence, the number of species recorded for the particular ailment is indirectly proportional to Fic value. For example skeleto-muscular system disorders had the lowest Fic of 0.63 , but this ailment category ranks third in the number of use reports (61) and number of taxa (23) attributed to this category. It may be due to the lack of communication among the informants in the study area who are practicing this ailment category (Rokaya et al., 2010) or it may be due to the lack of skeleto-muscular system disorders among the studied tribal people (Ragupathy et al., 2008).

At the same time, the highest use-reports with desired number of species show significant Fic value. Factors such as number of taxa and use reports (Figure 6) are determining the Fic value of the given plant. In this study, the range of Fic value (Table 4) is between 0.60 and 1.00 ; besides, when compared with the mean and standard deviation, the lower Fic values were recorded in general health problems $(0.60)$ and genitor-urinary system disorders (0.71), and skeleto-muscular system disorders 


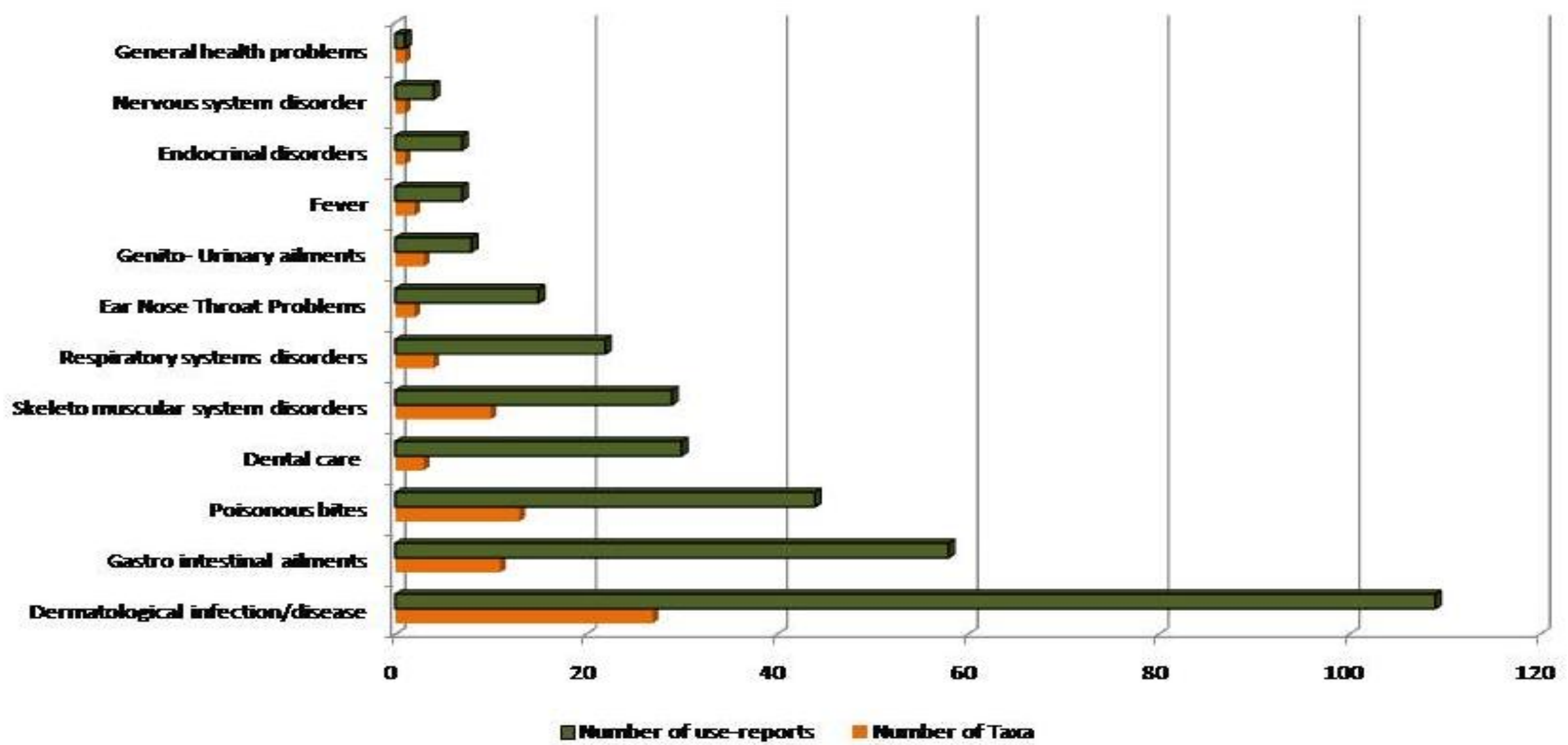

Figure 6. Number of use reports vs. ailment categories treated by the studied tribal people.

(0.78). Fic values obtained for the reported categories indicate the degree of knowledge shared regarding the use of medicinal herbs in the treatment of the ailment.

\section{Conclusion}

The wealth of the tribal knowledge of medicinal plants points to a great potential for research and the discovery of new drugs to fight diseases, obtaining other new uses (Ignacimuthu et al., 2008). Further attention is necessary on plan species which are having high fidelity level. The plants with high use value and informant consensus factor in the study recommended that, they can be ethnobotanically useful and provide the researchers with a quantitative tool to examine the relationship between taxonomic groups based on their ethnopharmacological uses.

There is no doubt that the 15 new recorded plant species are awaiting search for new uses. So, further scientific assessment of these medicines for phytochemical, biological and clinical studies is however greatly needed. The 
Table 3. Ingredients and other medicinal plants added for the preparation of herbal medicines by Hooralis of Vilangombai, Tamil Nadu, India.

\begin{tabular}{|c|c|c|}
\hline Botanical name & Other plants added in medicinal preparation & Other ingredients added \\
\hline Abutilon indicum(Link.) Sweet & Ocimum sanctum, Acalypha indica & - \\
\hline Acaceae leucocephala (Roxb.) Willd. & - & clay \\
\hline Acalypha alnifolia Klein. ex. Willd. & Ocimum sanctum, Abutilon indicum & - \\
\hline Acalypha indica L. & - & - \\
\hline Achyranthus aspera L. & - & - \\
\hline Anisomeles malabarica (L.) R.Br. ex. Sims. & Ficus sps & \\
\hline Amaranthus cruentus L. & Allium cepa, Cuminum cyminum & - \\
\hline Amaranthus spinosus $\mathrm{L}$. & Boerhaavia diffusa & - \\
\hline Barleria prionitis $\mathrm{L}$ & Curcuma longa, Allium cepa & - \\
\hline Bauhinia tomentosa L. & Ziziphus oenoplia & - \\
\hline Boerhaavia diffusa $L$. & Malvastrum coromandalianum & - \\
\hline Boussingaultia baselloides & Luffa acutangula, chilly & - \\
\hline Calotropis gigantea (L.) W. T. Aiton & - & Coconut oil \\
\hline Canavalia virosa (Roxb.) Wight \& Arn. & - & - \\
\hline Carica papaya L. & - & - \\
\hline Cardiospermum helicacabum L. & Allium sativum, Piper nigram & - \\
\hline Cassia angustifolia Vahl. & - & - \\
\hline Chlorophytum tuberosum (Roxb.) & Curcuma longa & - \\
\hline Chloroxylon swietenia Dc. & - & Salt \\
\hline Cissus quadrangularis $\mathrm{L}$. & Allium cepa & - \\
\hline Commiphora caudata (Wight \& Arn.) Engler. & Psidium guava & - \\
\hline Datura metel L. & - & - \\
\hline Dioscorea pentaphylla L. & - & Honey \\
\hline Euphorbia ligularia Roxb. & Curcuma longa & - \\
\hline Euphorbia tirucalli L. & - & - \\
\hline Evolvulus alsinoides $\mathrm{L}$. & - & - \\
\hline Ficus racemosa $\mathrm{L}$. & Anisomeles malabarica & - \\
\hline Gynandropsis pentaphylla (L.) Dc. & - & - \\
\hline Hibiscus micranthus $\mathrm{L}$. & Cardiospermum helicacabum & - \\
\hline Jasminum angustifolium (L.) Willd. & Cissus quadrangularis, Allium cepa & - \\
\hline Justicia tranquebariensis L.f. & Allium cepa & - \\
\hline Leucas aspera (Willd.) Link. & Pongamea pinnata & - \\
\hline Luffa acutangula (L.) Roxb. & Boussingaultia baselloides & - \\
\hline Malvastrum coromandalianum (L.) Gercke. & Boerhaavia diffusa & - \\
\hline Mucuna atropurpurium (Roxb.) DC.ex.W \& A. & Curcuma longa & - \\
\hline Passiflora foetida $\mathrm{L}$. & - & - \\
\hline Pongamea pinnata (L.) & - & Cow ghee \\
\hline Prosopsis cineraria (L.) Druce & - & Honey \\
\hline Pergularia daemia (forsk.) & - & - \\
\hline Rivea hypocrateriformis (Desr.) Choisy & - & - \\
\hline Phyllanthus emblica L. & Mangifera indica & - \\
\hline Rivea hypocrateriformis (Desr.) Choisy. & Jasminum angustifolium & - \\
\hline Solanum pubescens Ruiz. \& Pav. & - & - \\
\hline Strychnos nux-vomica L. & - & - \\
\hline Tinospora cardifolia (Thunb.) Miers. & Musa paradisiaha & - \\
\hline Toddalia asiatica (L.) Lam. & - & - \\
\hline Vitex negundo L. & - & - \\
\hline Ziziphus oenoplia L. & Ficus tomentosa & - \\
\hline
\end{tabular}


Table 4. Fidelity level (FL) values for common medicinal plants used by Hooralis tribe.

\begin{tabular}{|c|c|c|}
\hline Ailment category & Most preferred species with specific ailment & FL (\%) \\
\hline \multirow{2}{*}{ Dental care } & Carica papaya & 100 \\
\hline & Solanum pubescens & 55.55 \\
\hline \multirow{19}{*}{ Dermatological infection/Diseases } & Abutilon indicum & 100 \\
\hline & Acalypha indica & 71.42 \\
\hline & Amaranthus spinosus & 100 \\
\hline & Barleria prionitis & 100 \\
\hline & Boerhaavia diffusa & 57.14 \\
\hline & Boussingaultia baselloides & 16.67 \\
\hline & Calotropis gigantea & 100 \\
\hline & Chloroxylon swietenia & 100 \\
\hline & Commiphora caudata & 100 \\
\hline & Datura metel & 66.66 \\
\hline & Euphorbia ligularia & 100 \\
\hline & Evolvulus alsinoides & 100 \\
\hline & Ficus racemosa & 33.33 \\
\hline & Hibiscus micranthus & 60 \\
\hline & Mucuna atropurpurium & 50 \\
\hline & Pongamea pinnata & 13.33 \\
\hline & Tinospora cardifolia & 66.66 \\
\hline & Toddalia asiatica & 100 \\
\hline & Strychnos nux-vomica & 35.71 \\
\hline Ear Nose Throat problems & Gynandropsis pentaphylla & 100 \\
\hline Endocrinal disorders & Pongamea pinnata & 46.66 \\
\hline \multirow{2}{*}{ Fever } & Pergularia daemia & 100 \\
\hline & Strychnos nux-vomica & 21.42 \\
\hline \multirow{11}{*}{ Gastro Intestinal ailments } & Achyranthus aspera & 100 \\
\hline & Bauhinia tomentosa & 100 \\
\hline & Cissus quadrangularis & 100 \\
\hline & Ficus racemosa & 55.55 \\
\hline & Jasminum angustifolium & 55.55 \\
\hline & Justicia tranquebariensis & 100 \\
\hline & Pongamea pinnata & 20 \\
\hline & Rivea hypocrateriformis & 100 \\
\hline & Phyllanthus emblica & 100 \\
\hline & Solanum pubescens & 44.44 \\
\hline & Ziziphus oenoplia & 100 \\
\hline \multirow{3}{*}{ General health problems } & Tinospora cardifolia & 33.33 \\
\hline & Jasminum angustifolium & 44.44 \\
\hline & Amaranthus cruentus & 33.33 \\
\hline \multirow{3}{*}{ Genito urinary ailments } & Anisomeles malabarica & 100 \\
\hline & Amaranthus cruentus & 66.66 \\
\hline & Ficus racemosa & 11.11 \\
\hline Nervous system disorder & Datura metel & 33.33 \\
\hline \multirow{3}{*}{ Poisonous bites } & Acalypha indica & 28.57 \\
\hline & Boussingaultia baselloides & 83.33 \\
\hline & Cassia angustifolia & 100 \\
\hline
\end{tabular}


Table 4. Contd.

\begin{tabular}{llc}
\hline & Chlorophytum tuberosum & 100 \\
\cline { 2 - 2 } & Euphorbia tirucalli & 100 \\
\cline { 2 - 2 } & Leucas aspera & 100 \\
\cline { 2 - 2 } Respiratory system diseases & Pongamea pinnata & 20 \\
\cline { 2 - 2 } & Prosopsis cineraria & 100 \\
\hline & Passiflora foetida & 100 \\
\cline { 2 - 3 } Skeleto muscular system disorders & Dioscorea pentaphylla & 100 \\
\cline { 2 - 3 } & Cardiospermum helicacabum & 44.44 \\
\cline { 2 - 3 } & Acaceae leucocephala & 60 \\
\cline { 2 - 3 } & Cardiospermum helicacabum & 22.22 \\
\cline { 2 - 3 } & Mucuna atropurpurium & 40 \\
\cline { 2 - 3 } & Strychnos nux-vomica & 50 \\
\cline { 2 - 3 } & Vitex negundo & 42.85 \\
\hline
\end{tabular}

Table 5. Informant consensus factor for collected used medicinal plants.

\begin{tabular}{clccc}
\hline S/N & Ailment category & $\begin{array}{c}\text { Number of use- } \\
\text { reports (Nur) }\end{array}$ & $\begin{array}{c}\text { Number of taxa } \\
\text { (Nt) }\end{array}$ & $\begin{array}{c}\text { Informant consensus } \\
\text { factor (Fic) }\end{array}$ \\
\hline 1 & Dental care & 20 & 2 & 0.94 \\
2 & Dermatological Infection/Diseases & 109 & 22 & 0.80 \\
3 & Ear Nose Throat problems & 11 & 1 & 1 \\
4 & Endocrinal disorders & 7 & 1 & 1 \\
5 & Fever & 7 & 2 & 0.83 \\
6 & Gastro-intestinal ailments & 59 & 11 & 0.82 \\
8 & General health problems & 6 & 3 & 0.60 \\
7 & Genito-Urinary ailments & 8 & 3 & 0.71 \\
9 & Nervous system disorders & 4 & 1 & 1.00 \\
10 & Poisonous Bites & 44 & 9 & 0.81 \\
11 & Respiratory system diseases & 22 & 4 & 0.85 \\
12 & Skeleto muscular system disorders & 29 & 7 & 0.78 \\
\hline
\end{tabular}

investigation is still incomplete, due to the vast area and wild animal threatening; hence, further survey will be needed to complete the knowledge exploitation which will also cover all divisions of Sathyamangalam forest indeed. Before completing civilization, the exploitation of traditional knowledge may be the right key for pharmacological inventions. The wide use of local flora by the tribal people suggests that cultivation and conservation of indigenous plants should be encouraged and there is a need for intensive work in this direction which may help tribal development (Anisuzzaman et al., 2007). Besides, younger generations should get awareness about traditional knowledge of their community and necessity. Hence, the encouragement from the organizations may promote the present status and we may conserve the medicinal plants as well as traditional knowledge.

\section{AKNOWLEDGEMENTS}

The authors would like to thank the Forest Ranger and Guard of Sathyamangalam forest, Vilangombai division for their help to approach the Hoorali tribes and Mr. Vijayakumar for his kind support during the survey.

\section{REFERENCES}

Adetutu A, Morgan WA, Corcoran O (2011). Ethnopharmacological survey and in vitro evaluation of wound-healing plants used in South- 
western Nigeria. J. Ethnopharmacol. 137:50-56.

Alegesaboopathi C (2009). Ethnomedicinal plants and their utilization by villagers in Kumaragiri hills of Salem district of Tamil Nadu, India. Afr. J. Trad. Comp. Alt. Med. 6(3):222-227.

Anisuzzaman M, Rahman AHMM, Harun-Or-Rashid M, Naderuzzaman ATM, Islam AKMR (2007). An Ethnobotanical Study of Madhupur, Tangail. J. App. Sc. Res. 3(7):519-530.

Arunachalam K, Parimelazhagan T (2011). Ethnobotanical observations among Hooralis Tribes in kadambur hills (kalkadambur), Erode District, Tamil Nadu. Global J. Pharmacol. 5(3):117-121.

Asase A, Akwetey GA, Achel DG (2010). Ethnopharmacological use of herbal remedies for the treatment of malaria in the Dangme West District of Ghana. J. Ethnopharmacol. 129:367-376.

Ayyanar M, Ignacimuthu S (2011). Ethnobotanical survey of medicinal plants commonly used by Kani tribals in Tirunelveli hills of Western Ghats, doi:10.1016/j.jep.2011.01.029. India. J. Ethnopharmacol. 134(3):851-864.

Băgcı Y (2000). Ethnobotanical features of Aladăglar (Yahyalı, Kayseri) and its vicinity. Herb J. Syst Bot. 7:89-94.

Barnert J, Messmann H (2008). Management of lower gastrointestinal tract bleeding. Best Practice and Research in Clin. Gastroenterol. 22:295-312.

Begossi A (1996). Use of ecological methods in ethnobotany: diversity indices. Eco. Bot., 50:280-289.

Bonet MA, Parada M, Selga A, Valles J (1999). Studies on pharmaceutical ethnobotany in the regions of L'Alt Emporda and Les Guilleries (Catalonia, Iberian Peninsula). J. Ethnopharmacol. 68:145168.

Chellaiah M, Muniappan A, Nagappan R, Savarimuthu I (2006). Medicinal plants used by traditional healers in Kancheepuram District of Tamil Nadu, India. J. Ethnobiol. Ethnomed. 2:43.

Coleta M, Campos MG, Cotrim MD, Da Cunha AP (2001). Comparative evaluation of Melissa officinalis L., Tilia europaea L., Passiflora edulis Sims. and Hypericum perforatum $\mathrm{L}$. in the elevated plus maze anxiety test. Pharmacopsychiatry. 34:20-21.

Doi T, Nima DN, Sumpam T, Arya SC, Bhaskar R, Samal PK, Mandal M (2011). An inventory of the ethnobotanicals used as anti-diabetic by a rural community of Dhemaji district of Assam, Northeast India. J. Ethnopharmacol. 138:345-350.

Gbeassor M, Koumaglo HK, Awang DVC, Durst J, Mackinnon S, Arnason JT (1996). Development of ethical phytomedicines for Togo, West Africa. In: Hostettman K, Chinyanganya M, Mai M Wolfender, J$\mathrm{L}$ (Eds.), Chemistry, Biological and Pharmacological Properties of African Medicinal Plants. University of Zimbabwe Publications pp. 211-219.

Hansel R (1972). Medicinal plants and empirical drug research. In: Swain T. (Ed.), Plants in the Development of Modern Medicine. Harvard University Press, Boston pp. 161-174.

Heinrich M, Ankli A, Frei B, Weimann C, Sticher O (1998). Medicinal plants in Mexico: healers' consensus and cultural importance. Soc. Sci. Med. 47:91-112.

Ignacimuthu S, Ayyanar M, Sankara Sivaraman K (2006). Ethnobotanical investigations among tribes in Madurai District of Tamil Nadu (India). J. Ethnobiol. Ethnomed. 2:25.

Ignacimuthu S, Ayyanar M, Sankarasivaraman K (2008). Ethnobotanical study of medicinal plants used by Paliyar tribals in Theni district of Tamil Nadu, India. Fitoterapia 79:562-568.

Kaya G (2006). Discussion of P\&P model used for estimating option value of forest ecosystems as medicinal plant resources. J. Bartın Faculty For. pp. 23-32.

Leduc C, Coonishish J, Haddad P, Cuerrier A (2006). Plants used by the Cree Nation of Eeyou Istchee (Quebec, Canada) for the treatment of diabetes: A novel approach in quantitative ethnobotany. J. Ethnopharmacol. 105:55-63.

Martin G (1995). Ethnobotany: A methods Manual. A People and Plants Conservation Manual. WWF International, UNESCO and Royal Botanic Gardens, Kew. Chapman and Hall, London.

Mesfin F, Demissew S, Teklehaymanot T (2009). An ethnobotanical study of medicinal plants in Wonago Woreda, SNNPR, Ethiopia. J. Ethnobiol. Ethnomed. 5:28.
Moerman DE (2007). Agreement and meaning: rethinking consensus analysis. J. Ethnopharmacol. 112:451-460.

Mulet L (1991). Estudio Etnobotanico de la Provincia de Castello. Disputacion de Castello, Castello P. 596.

Muthu C, Ayyanar M, Raja N, Ignacimuthu S (2006). Medicinal plants used by traditional healers in Kancheepuram district of Tamil Nadu, India. J. Ethnobiol. Ethnomed., 2:43.

Novais MH, Santos I, Mendes S, Pinto-Gomes C (2004). Studies on pharmaceutical ethnobotany in Arrabida Natural Park (Portugal). J. Ethnopharmacol. 3:183-195.

Pandikumar P, Chellappandian M, Mutheeswaran S, Ignacimuthu S (2011). Consensus of local knowledge on medicinal plants among traditional healers in Mayiladumparai block of Theni District, Tamil Nadu, India. J. Ethnopharmacol. 134:354-362.

Poongodi A, Thilagavathi S, Aravindhan V, Rajendran A (2011). Observations on some ethnomedicinal plants in Sathyamangalam forests of Erode district, Tamil Nadu, India. J. Med. Plants Res. 5(19):4709-4714.

Principe PE (1991). Valuing the biodiversity of medicinal plants. In: Akerele O, Heywood V, Synge H (Eds.), Conservation of Medicinal Plants. Proceedings of an International Consultation. 21-27 March 1988 Chiang Mai Thailand, Cambridge University Press, Cambridge pp. 79-124.

Ragupathy S, Steven NG, Maruthakkutti M, Velusamy B, UI-Huda MM (2008). Consensus of the 'Malasars' traditional aboriginal knowledge of medicinal plants in the Velliangiri holy hills, India. http://www.ethnobiomed.com /content/4/1/8. J. Ethnobiol. Ethnomed., $4: 8$.

Rajakumar N, Shivanna MB (2009). Ethnomedicinal application of plants in the east- ern region of Shimoga District, Karnataka, India. J. Ethnopharmacol. 126:64-73.

Revathi P, Parimelazhagan T (2010). Traditional Knowledge on Medicinal Plants Used by the Irula Tribe of Hasanur Hills, Erode District, Tamil Nadu, India. Ethnobot. Leaflets 14:136-60.

Rivera D, Obon C, Inocencio C, Heinrich M, Verde A, Fajardo J, Llorach R (2005). The ethnobotanical study of local mediterranean food plants as medicinal resources in southern spain. J. physiol. pharmacol., 56(1):97.114.

Rokaya MB, Munzbergova Z, Timsina B (2010). Ethnobotanical study of medicinal plants from the Humla district of western Nepal. $J$. Ethnopharmacol. 130:485-504.

Sears RR, Padoch C, Pinedo-Vasquez M (2007). Amazon forestry transformed: integrating knowledge for small holder timber management in eastern Brazil. Hum. Ecol. 35:697-707.

Senthilkumar M, Gurumoorthi P, Janardhanan K (2006). Some medicinal plants used by Irular, the tribal people of Marudhamalai hills, Coimbatore, Tamil Nadu. Nat. Prod. Rad. 5(5):382-388.

Teklehaymanot T, Giday M (2007). Ethnobotanical study of medicinal plants used by people in Zegie Peninsula, northwestern Ethiopia. J. Ethnobiol. Ethnomed. 3:12.

Turner N (1995). Ethnobotany today in northwestern North America. In: Schultes RE, Von Reis S, editors. Ethnobotany: Evolution of a discipline. Portland, OR: Dioscorides Press pp. 264-283. 